\title{
IMMUNOLOGICAL STUDIES OF PNEUMOCOCCAL PNEUMONIA IN PATIENTS TREATED WITH PENICILLIN ${ }^{1}$
}

\author{
By WILLIAM S. JORDAN, JR., GEORGE F. BADGER, AND JOHN H. DINGLE \\ (From the Departments of Preventive Medicine and of Medicine, School of Medicine, Western \\ Reserve University, and the University Hospitals, Cleveland, Ohio)
}

(Received for publication July 12, 1949)

Immunological studies of pneumococcal infections in both man (1-8) and animals (9-13) have shown that the development of specific antibodies is not affected by early therapy with sulfonamide drugs. In contrast, early penicillin therapy of rabbits and mice (14) and of rats (15) infected with pneumococci has been observed to suppress or decrease the antibody response of these animals. Meager data are available for patients treated with penicillin $(8,16)$. The present study was undertaken (1) to examine the immunological response of patients with pneumococcal pneumonia treated with penicillin and (2) to determine the effect of early penicillin therapy on the immune response.

\section{MATERIALS AND METHODS}

During the winter of $1947-48,44$ patients were selected for study on the basis of the following criteria: a clinical picture compatible with the diagnosis of pneumococcal infection, the occurrence of either a shaking chill or pleural pain, and the presence of typable pneumococci in the sputum. Forty-two of the patients had pulmonary infiltration demonstrable by roentgenographic and physical examinations. Twenty-six, or 60 per cent, of the cases experienced upper respiratory symptoms for from one day to three weeks preceding the sudden onset of severe symptoms. The acute onset of the disease was defined as the time of occurrence of the shaking chill or pleural pain, whichever came first.

Twenty-nine patients received initial penicillin doses of from 20,000 to 50,000 units intramuscularly; 12 patients were given 100,000 units, and three patients 300,000 units. Subsequent dosage in 33 cases ranged from 20,000 to 50,000 units every two to three hours. Four patients received 100,000 units every eight hours; six patients received 100,000 units every 12 hours. One patient was treated with 300,000 units of procaine penicillin once a day. Duration of treatment varied from five to 27 days, and total dosage ranged from 1 million to 10 million units.

Agglutination tests were done using a 0.3 per cent

1 This investigation was supported in part through the Commission on Acute Respiratory Diseases, Army Epidemiological Board, Office of the Surgeon General, U. S. Army, and by grants from the Brush Foundation, the Cleveland Foundation, the S. P. Fenn Trust, and Mr. Philip R. Mather. formalinized saline suspension of an 18-hour culture, standardized to give a turbidity approximating No. 5 in the McFarland scale. Serial dilutions of serum, in amounts of $0.5 \mathrm{ml}$., were mixed with an equal volume of suspension, incubated for four hours at $37^{\circ} \mathrm{C}$. and read after storage overnight at $4^{\circ} \mathrm{C}$. Type-specific rabbit sera were used as controls. The end-point was read as the final dilution of serum producing grossly floccular agglutination. The titer is expressed as the reciprocal of this dilution. Development of detectable agglutinins or a four-fold or greater increase in titer during convalescence was considered to be indicative of an antibody response.

Mouse protection tests were performed us.ng strains of pneumococci maintained by daily mouse passage. Mouse virulent strains ${ }^{2}$ were available for all types except type 33. For each test, the heart's blood of a mouse, inoculated five hours previously with the specific type of pneumococci, was transferred in blood broth and the resulting culture incubated for 18 hours. The serum was diluted in 0.85 per cent $\mathrm{NaCl}$ solution so that $0.1 \mathrm{ml}$. was contained in $0.5 \mathrm{ml}$. Decimal dilutions of the pneumococcal culture were injected intraparitoneally in $0.5 \mathrm{ml}$. amounts; immediately thereafter $0.5 \mathrm{ml}$. of the serum dilution was administered by the same route. Five mice were used for each dilution, and at least four consecutive decimal dilutions of organisms were used in testing each serum. In the event that an end-point was not reached, all sera from that patient were retested. A control titration was performed with each test, employing broth in place of serum, and a 50 per cent lethal dose (LD50) was arbitrarily selected as the end-point, for comparison with the serum titrations. The titer was considered to be the degree of protection, expressed in terms of LD50, conferred by 0.1 $\mathrm{ml}$. of serum against the homologous strain of pneumococcus. An increase in the protective titer of 100 or more in the convalescent-phase serum, in comparison with the acute-phase serum, was considered to be a significant immunological response.

\section{RESULTS}

The results of the antibody studies, and the data pertaining to therapy, bacteremia, and complications, are shown in Table I. The cases are grouped according to the type of pneumococcus found cul-

2 Types 5, 7, 12, 18, 27 and 33 were obtained from Dr. H. W. Lyall of the New York State Department of Health. 
TABLE I

Agglutinin and mouse protection titers in patients with pmeumococcal pneumonia treated with penicillin

\begin{tabular}{|c|c|c|c|c|c|c|c|c|c|c|c|}
\hline \multirow[b]{2}{*}{$\begin{array}{l}\text { Case } \\
\text { no. }\end{array}$} & \multirow{2}{*}{$\begin{array}{l}\text { Sex } \\
\text { and } \\
\text { age }\end{array}$} & \multirow[b]{2}{*}{ Type } & \multicolumn{4}{|c|}{ Penicillin therapy } & \multirow[b]{2}{*}{$\begin{array}{l}\text { Preceding } \\
\text { URI }\end{array}$} & \multicolumn{3}{|c|}{ Results of teats } & \multirow[b]{2}{*}{ Complications } \\
\hline & & & $\underset{\text { to } R x}{\text { Time }}$ & $\begin{array}{c}\text { Initial } \\
\text { dose }\end{array}$ & $\begin{array}{l}\text { Total } \\
\text { dose }\end{array}$ & $\begin{array}{l}\text { No. } \\
\text { days }\end{array}$ & & $\begin{array}{l}\text { Day of } \\
\text { disease }\end{array}$ & 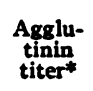 & $\begin{array}{c}\text { Mouse } \\
\text { pro- } \\
\text { tectiont }\end{array}$ & \\
\hline 1 & F-28 & 1 & 3 hrs. & 30,000 & $\begin{array}{c}\times 100,000 \\
13.2\end{array}$ & 6 & None & $\begin{array}{r}1 \\
10 \\
41\end{array}$ & $\begin{array}{l}0 \\
0 \\
0\end{array}$ & $\begin{array}{l}10^{4} \\
10^{4} \\
10^{4}\end{array}$ & None \\
\hline 2 & M-32 & 1 & 7 hrs. & 40,000 & 18.6 & 6 & 3 days & $\begin{array}{r}1 \\
8 \\
23\end{array}$ & $\begin{array}{l}0 \\
4 \\
0\end{array}$ & $\begin{array}{r}<10 \\
10^{4} \\
10^{3}\end{array}$ & None \\
\hline 3 & M-38 & 1 & 12 hrs. & 100,000 & 15.7 & 9 & 7 days & $\begin{array}{r}1 \\
8 \\
28\end{array}$ & $\begin{array}{l}0 \\
0 \\
0\end{array}$ & $\begin{array}{r}<10 \\
>10^{4} \\
10^{4}\end{array}$ & None \\
\hline 4 & F-23 & 1 & $48 \mathrm{hrs}$. & 130,000 & 14.0 & 7 & 3 weeks & $\begin{array}{r}7 \\
26\end{array}$ & $\begin{array}{l}0 \\
4\end{array}$ & $\begin{array}{r}>10^{4} \\
10^{4}\end{array}$ & $\begin{array}{l}6 \text { months pregnant; ECG } \\
\text { evidence of pericarditis }\end{array}$ \\
\hline 5 & F-64 & 1 & 3 days & 30,000 & 15.6 & 7 & None & $\begin{array}{r}5 \\
12\end{array}$ & $\begin{array}{r}0 \\
16\end{array}$ & $\begin{array}{r}<10 \\
10^{4}\end{array}$ & None \\
\hline 6 & M-39 & 1 & 4 days & 100,000 & 20.0 & 10 & 6 days & $\begin{array}{r}6 \\
13 \\
24\end{array}$ & $\begin{array}{l}0 \\
0 \\
0\end{array}$ & $\begin{array}{l}10^{3} \\
10^{4} \\
10^{3}\end{array}$ & None \\
\hline 7 & M-62 & 1 & 5 days & 50,000 & 51.0 & 12 & 2 weeks & $\begin{array}{l}12 \\
23\end{array}$ & $\begin{array}{r}0 \\
16\end{array}$ & $\begin{array}{l}10^{3} \\
10^{4}\end{array}$ & Latent syphilis \\
\hline 8 & M-63 & 2 & 24 hrs. & 100,000 & 24.0 & 8 & 6 days & $\begin{array}{l}10 \\
17\end{array}$ & $\begin{array}{r}8 \\
32\end{array}$ & $\begin{array}{r}>10^{4} \\
10^{4}\end{array}$ & $\begin{array}{l}\text { Unresolved pneumonia; } \\
\text { subsequently died of mili- } \\
\text { ary tuberculosis }\end{array}$ \\
\hline 9 & M-47 & 2 & $26 \mathrm{hrs}$. & 50,000 & 102.0 & 18 & None & $\begin{array}{l}15 \\
23\end{array}$ & $\begin{array}{l}0 \\
0\end{array}$ & $\begin{array}{r}10 \\
0\end{array}$ & $\begin{array}{l}\text { Bacteremia; delayed re- } \\
\text { resolution }\end{array}$ \\
\hline 10 & M-22 & 2 & $26 \mathrm{hrs}$. & 100,000 & 14.0 & 7 & None & $\begin{array}{r}3 \\
10\end{array}$ & $\begin{array}{r}0 \\
32\end{array}$ & $\begin{array}{c}0 \\
>10^{4}\end{array}$ & None \\
\hline 11 & F-46 & 2 & $27 \mathrm{hrs}$. & 50,000 & 33.7 & 17 & 5 days & $\begin{array}{r}2 \\
9 \\
17 \\
23\end{array}$ & $\begin{array}{r}0 \\
32 \\
32 \\
64\end{array}$ & $\begin{array}{c}0 \\
10^{4} \\
10^{4} \\
10^{4}\end{array}$ & Bacteremia; pleuritis \\
\hline 12 & M-55 & 2 & 4 days & 30,000 & 56.8 & 17 & None & $\begin{array}{r}5 \\
12 \\
19\end{array}$ & $\begin{array}{r}0 \\
128 \\
64\end{array}$ & $\begin{array}{r}0 \\
>10^{5} \\
>10^{6}\end{array}$ & Delayed resolution \\
\hline 13 & M-46 & 2 & 4 days & 30,000 & 30.0 & 13 & 3 weeks & $\begin{array}{r}5 \\
12 \\
102\end{array}$ & $\begin{array}{l}0 \\
0 \\
4 \ddagger\end{array}$ & $\begin{array}{l}0 \\
0 \\
0\end{array}$ & $\begin{array}{l}\text { Multiple myeloma; de- } \\
\text { layed resolution. Died } \\
\text { of pneumococcal menin- } \\
\text { gitis, type } 2\end{array}$ \\
\hline 14 & M-48 & 2 & 4 days & 100,000 & 33.0 & 12 & 10 days & $\begin{array}{r}5 \\
15\end{array}$ & $\begin{array}{r}8 \\
64\end{array}$ & $\begin{array}{l}10 \\
10^{3}\end{array}$ & Delayed resolution \\
\hline 15 & M-53 & 3 & 12 hrs. & 40,000 & 30.8 & 9 & None & $\begin{array}{l}1 \\
8\end{array}$ & $\begin{array}{l}0 \\
0\end{array}$ & $\begin{array}{l}<10 \\
10^{4}\end{array}$ & None \\
\hline 16 & M-77 & 3 & $16 \mathrm{hrs}$. & 40,000 & 12.8 & 6 & 2 weeks & $\begin{array}{l}2 \\
9\end{array}$ & $\begin{array}{l}\mathbf{0} \\
\mathbf{0}\end{array}$ & $\begin{array}{c}0 \\
10^{2}\end{array}$ & None \\
\hline
\end{tabular}

* Reciprocal of highest dilution showing floccular agglutination; $0=<4$.

+ Number of 50 per cent fatal doses protected by $0.1 \mathrm{ml}$. of serum.

$\mp$ Agglutination attributed to hyperglobulinemia due to multiple myeloma. 
IMMUNOLOGICAL STUDIES OF PNEUMOCOCCAL PNEUMONIA

TABLE I-Continued

\begin{tabular}{|c|c|c|c|c|c|c|c|c|c|c|c|}
\hline \multirow{2}{*}{$\begin{array}{l}\text { Case } \\
\text { no. }\end{array}$} & \multirow{2}{*}{$\begin{array}{l}\text { Sex } \\
\text { and } \\
\text { age }\end{array}$} & \multirow[b]{2}{*}{ Type } & \multicolumn{4}{|c|}{ Penicillin therapy } & \multirow[b]{2}{*}{$\begin{array}{l}\text { Preceding } \\
\text { URI }\end{array}$} & \multicolumn{3}{|c|}{ Results of tests } & \multirow[b]{2}{*}{ Complications } \\
\hline & & & $\begin{array}{l}\text { Time } \\
\text { to } \mathbf{R x}\end{array}$ & $\begin{array}{c}\text { Initial } \\
\text { dose }\end{array}$ & $\begin{array}{l}\text { Total } \\
\text { doee }\end{array}$ & $\begin{array}{l}\text { No. } \\
\text { days }\end{array}$ & & $\begin{array}{l}\text { Day of } \\
\text { disease }\end{array}$ & $\begin{array}{c}\text { Agglu- } \\
\text { tininin } \\
\text { titer" }\end{array}$ & $\begin{array}{c}\text { Mouse } \\
\text { pro- } \\
\text { tectiont }\end{array}$ & \\
\hline 17 & M-38 & 3 & 24 hrs. & 50,000 & $\begin{array}{c}\times 100.000 \\
52.0\end{array}$ & 13 & None & $\begin{array}{r}2 \\
9 \\
17\end{array}$ & $\begin{array}{l}\mathbf{0} \\
0 \\
\mathbf{0}\end{array}$ & $\begin{array}{l}10^{4} \\
10^{4} \\
10^{4}\end{array}$ & $\begin{array}{l}\text { Pneumonia } 11 \text { weeks pre- } \\
\text { viously treated at an- } \\
\text { other hospital }\end{array}$ \\
\hline 18 & F-68 & 3 & 24 hrs. & 300,000 & 15.2 & 10 & 2 days & $\begin{array}{r}4 \\
12 \\
15\end{array}$ & $\begin{array}{r}0 \\
32 \\
32\end{array}$ & $\begin{array}{l}<10 \\
>10^{\circ} \\
10^{\circ}\end{array}$ & None \\
\hline 19 & M-53 & 3 & 3 days & 30,000 & 16.8 & 7 & None & $\begin{array}{r}4 \\
11\end{array}$ & $\begin{array}{l}\mathbf{0} \\
\mathbf{0}\end{array}$ & $\begin{array}{l}0 \\
0\end{array}$ & ? silicosis \\
\hline 20 & F-61 & 3 & 3 days & 50,000 & 33.0 & 9 & 4 days & $\begin{array}{r}6 \\
14\end{array}$ & $\begin{array}{l}\mathbf{0} \\
\mathbf{0}\end{array}$ & $\begin{array}{r}<10^{2} \\
10^{4}\end{array}$ & None \\
\hline 21 & M-68 & 3 & 3 days & 100,000 & 25.0 & 10 & 1 day & $\begin{array}{r}7 \\
14 \\
23\end{array}$ & $\begin{array}{l}0 \\
0 \\
0\end{array}$ & $\begin{array}{c}10^{3} \\
0 \\
0\end{array}$ & $\begin{array}{l}\text { Bacteremia; delayed res- } \\
\text { olution }\end{array}$ \\
\hline 22 & F-53 & 4 & $18 \mathrm{hrs}$. & 30,000 & 34.0 & 15 & 7 days & $\begin{array}{r}3 \\
10 \\
17\end{array}$ & $\begin{array}{l}0 \\
8 \\
4\end{array}$ & $\begin{array}{l}10 \\
<10^{3} \\
<10^{3}\end{array}$ & Sterile pleural effusion \\
\hline 23 & $F-44$ & 4 & $26 \mathrm{hrs}$. & 100,000 & 26.0 & 13 & 2 weeks & $\begin{array}{r}3 \\
11 \\
22\end{array}$ & $\begin{array}{l}0 \\
4 \\
0\end{array}$ & $\begin{array}{l}10 \\
10 \\
10\end{array}$ & $\begin{array}{l}\text { Metastatic carcinoma of } \\
\text { ovary }\end{array}$ \\
\hline 24 & F-60 & 4 & 4 days & 100,000 & 70.0 & 18 & 10 days & $\begin{array}{r}4 \\
12 \\
19\end{array}$ & $\begin{array}{l}0 \\
64 \\
64\end{array}$ & $\begin{array}{l}<10^{2} \\
<10^{2} \\
<10^{2}\end{array}$ & $\begin{array}{l}\text { Bacteremia; sterile } \\
\text { pleural effusion }\end{array}$ \\
\hline 25 & M-42 & 5 & $10 \mathrm{hrs}$. & 25,000 & 15.7 & 7 & 3 days & 13 & $\begin{array}{l}0 \\
0\end{array}$ & $<1$ & None \\
\hline 26 & M-55 & 5 & 5 days & 30,000 & 20.0 & 10 & 4 days & $\begin{array}{r}5 \\
12\end{array}$ & $\begin{array}{l}0 \\
0\end{array}$ & $\begin{array}{l}>10^{3} \\
>10^{5}\end{array}$ & None \\
\hline 27 & M-29 & 7 & 24 hrs. & 30,000 & 14.0 & 6 & 5 days & $\begin{array}{r}1 \\
22\end{array}$ & $\begin{array}{r}0 \\
16\end{array}$ & $\begin{array}{l}10^{2} \\
10^{5}\end{array}$ & None \\
\hline 28 & M-36 & 7 & 3 days & 30,000 & 10.0 & 5 & None & $\begin{array}{l}3 \\
7\end{array}$ & $\begin{array}{l}0 \\
8\end{array}$ & $\begin{array}{l}10 \\
10^{5}\end{array}$ & None \\
\hline 29 & M-58 & 7 & 3 days & 20,000 & 12.0 & 9 & 1 day & $\begin{array}{r}4 \\
12\end{array}$ & $\begin{array}{r}0 \\
16\end{array}$ & $\begin{array}{l}10 \\
10^{5}\end{array}$ & None \\
\hline 30 & M-52 & 8 & $2 \mathrm{hrs}$. & 300,000 & 21.0 & 7 & 2 weeks & $\frac{1}{7}$ & $\begin{array}{l}\mathbf{0} \\
\mathbf{0}\end{array}$ & $\begin{array}{r}0 \\
<1\end{array}$ & None \\
\hline 31 & F-50 & 8 & 20 hrs. & 50,000 & 25.0 & 7 & 10 days & $\begin{array}{r}1 \\
8 \\
16\end{array}$ & $\begin{array}{l}0 \\
4 \\
4\end{array}$ & $\begin{array}{c}0 \\
10^{3} \\
10^{3}\end{array}$ & None \\
\hline 32 & M-36 & 8 & $28 \mathrm{hrs}$. & 100,000 & 14.0 & 5 & None & $\begin{array}{r}4 \\
8 \\
19\end{array}$ & $\begin{array}{r}0 \\
0 \\
16\end{array}$ & $\begin{array}{c}0 \\
10^{3} \\
10^{4}\end{array}$ & None \\
\hline 33 & M-35 & 8 & 48 hrs. & 100,000 & 13.0 & 7 & None & $\begin{array}{r}4 \\
11\end{array}$ & $\begin{array}{l}\mathbf{0} \\
\mathbf{0}\end{array}$ & $\begin{array}{r}0 \\
10\end{array}$ & Latent syphilis \\
\hline 34 & M-55 & 8 & 4 days & 100,000 & 10.0 & 6 & 2 weeks & $\begin{array}{r}4 \\
11\end{array}$ & $\begin{array}{l}0 \\
0\end{array}$ & $\begin{array}{l}\mathbf{0} \\
\mathbf{0}\end{array}$ & Bacteremia \\
\hline 35 & M-56 & 8 & 4 weeks & 300,000 & 54.0 & 27 & None & $\begin{array}{l}28 \\
35\end{array}$ & $\begin{array}{l}\mathbf{0} \\
\mathbf{0}\end{array}$ & $\begin{array}{l}<1 \\
<10\end{array}$ & $\begin{array}{l}\text { Diabetic; bacteremia; } \\
\text { empyema; lung abscess; } \\
\text { broncho-pleural fistula }\end{array}$ \\
\hline
\end{tabular}


TABLE I-Continued

\begin{tabular}{|c|c|c|c|c|c|c|c|c|c|c|c|}
\hline \multirow[b]{2}{*}{$\begin{array}{c}\text { Case } \\
\text { no. }\end{array}$} & \multirow{2}{*}{$\begin{array}{l}\text { Sex } \\
\text { and } \\
\text { age }\end{array}$} & \multirow[b]{2}{*}{ Type } & \multicolumn{4}{|c|}{ Penicillin therapy } & \multirow[b]{2}{*}{$\begin{array}{l}\text { Preceding } \\
\text { URI }\end{array}$} & \multicolumn{3}{|c|}{ Results of tests } & \multirow[b]{2}{*}{ Complications } \\
\hline & & & $\underset{\text { to } R x}{\text { Time }}$ & $\begin{array}{c}\text { Initial } \\
\text { dose }\end{array}$ & $\begin{array}{l}\text { Total } \\
\text { dose }\end{array}$ & $\begin{array}{l}\text { No. } \\
\text { days }\end{array}$ & & $\begin{array}{l}\text { Day of } \\
\text { disease }\end{array}$ & $\begin{array}{c}\text { Agglu- } \\
\text { tinin } \\
\text { titer }^{*}\end{array}$ & $\begin{array}{c}\text { Mouse } \\
\text { pro- } \\
\text { tection† }\end{array}$ & \\
\hline 36 & F-68 & 12 & $16 \mathrm{hrs}$. & 100,000 & $\begin{array}{l}\times 100,000 \\
12.0\end{array}$ & 7 & 5 days & $\begin{array}{r}4 \\
12\end{array}$ & $\begin{array}{l}\mathbf{0} \\
\mathbf{0}\end{array}$ & $\begin{array}{r}10^{3} \\
>10^{6}\end{array}$ & Bacteremia \\
\hline 37 & M-81 & 12 & 2 days & 30,000 & 26.1 & 11 & None & $\begin{array}{r}3 \\
10\end{array}$ & $\begin{array}{l}\mathbf{0} \\
8\end{array}$ & $\begin{array}{l}10^{3} \\
10^{5}\end{array}$ & None \\
\hline 38 & $F-47$ & 12 & 3 days & 30,000 & 16.5 & 8 & 10 days & $\begin{array}{r}3 \\
10\end{array}$ & $\begin{array}{r}0 \\
128\end{array}$ & $\begin{array}{r}>10^{5} \\
10^{5}\end{array}$ & None \\
\hline 39 & M-53 & 12 & 4 days & 50,000 & 34.0 & 9 & None & $\begin{array}{r}5 \\
14\end{array}$ & $\begin{array}{l}\mathbf{0} \\
\mathbf{0}\end{array}$ & $\begin{array}{r}10^{3} \\
>10^{5}\end{array}$ & $\begin{array}{l}\text { Lymphosarcoma; } \\
\text { bacteremia }\end{array}$ \\
\hline 40 & F-34 & 18 & 7 hrs. & 50,000 & 17.5 & 9 & None & $\begin{array}{r}3 \\
10\end{array}$ & $\begin{array}{l}\mathbf{0} \\
\mathbf{0}\end{array}$ & $\begin{array}{c}0 \\
10^{3}\end{array}$ & None \\
\hline 41 & F.77 & 18 & 12 hrs. & 30,000 & 22.0 & 10 & None & $\begin{array}{l}1 \\
8\end{array}$ & $\begin{array}{l}\mathbf{0} \\
\mathbf{0}\end{array}$ & $\begin{array}{l}10^{2} \\
10^{2}\end{array}$ & $\begin{array}{l}\text { Hypertension; heart dis- } \\
\text { ease }\end{array}$ \\
\hline 42 & M-38 & 27 & $26 \mathrm{hrs}$. & 30,000 & 10.2 & 8 & 2 days & $\begin{array}{r}3 \\
10\end{array}$ & $\begin{array}{r}8 \\
16\end{array}$ & $\begin{array}{l}10 \\
10^{3}\end{array}$ & None \\
\hline 43 & M-41 & 33 & 5 days & 30,000 & 52.0 & 18 & None & $\begin{array}{r}6 \\
13\end{array}$ & $\begin{array}{r}0 \\
32\end{array}$ & & $\begin{array}{l}\text { Hydronephrosis; bacter- } \\
\text { emia; delayed resolution }\end{array}$ \\
\hline 44 & $F-61$ & 33 & 9 days & 50,000 & 44.0 & 10 & None & $\begin{array}{l}11 \\
18\end{array}$ & $\begin{array}{l}16 \\
32\end{array}$ & & None \\
\hline
\end{tabular}

turally and are arranged in order of the duration of illness at the time of therapy.

Either agglutinins or mouse protective antibodies, or both, developed in the serum of 75 per cent of the patients, the rise in titer appearing on the fifth to tenth day of disease. Twenty-two of the 44 patients, or 50 per cent, developed agglutinins. In two patients, agglutinins were present, but a change in titer of only two-fold was detected. One of these patients (case 42), although

TABLE II

The development of agglutinins and mouse protective antibodies in 44 cases of pneumococcal pneumonia treated with penicillin

\begin{tabular}{|c|c|c|c|c|c|c|c|c|c|c|}
\hline \multicolumn{3}{|c|}{ Cases } & \multicolumn{2}{|c|}{ Agglutinins } & \multicolumn{2}{|c|}{ Mouse protection } & \multicolumn{2}{|c|}{ Either } & \multicolumn{2}{|c|}{ Neither } \\
\hline Type & $\begin{array}{l}\text { Time to } \\
\text { treatment }\end{array}$ & No. & No. & per cent & No. & per cent & No. & per cent & No. & per cent \\
\hline \multirow{3}{*}{3 and 8} & Within 28 hours & 7 & 3 & 43 & 5 & 71 & 5 & 71 & 2 & 29 \\
\hline & $>28$ hours & 6 & 0 & 0 & 1 & 17 & 1 & 17 & 5 & 83 \\
\hline & Total & 13 & 3 & 23 & 6 & 46 & 6 & 46 & 7 & 54 \\
\hline \multirow{3}{*}{$\begin{array}{c}\text { All } \\
\text { others }\end{array}$} & Within 28 hours & 15 & 7 & 47 & 11 & 73 & 12 & 80 & 3 & 20 \\
\hline & $>28$ hours & 16 & 12 & 75 & 11 of 14 & 79 & 15 & 94 & 1 & 6 \\
\hline & Total & 31 & 19 & 61 & 22 of 29 & 76 & 27 & 87 & 4 & 13 \\
\hline \multirow{3}{*}{$\begin{array}{c}\text { All } \\
\text { types }\end{array}$} & Within 28 hours & 22 & 10 & 46 & 16 & 73 & 17 & 77 & 5 & 23 \\
\hline & $>28$ hours & 22 & 12 & 54 & 12 of 20 & 60 & 16 & 73 & 6 & 27 \\
\hline & Total & 44 & 22 & 50 & 28 of 42 & 67 & 33 & 75 & 11 & 25 \\
\hline
\end{tabular}


showing a significant increase in mouse protective antibodies, has not been classed as showing an agglutinin response. Only convalescent sera were available from the other patient (case 44) and the agglutinin titers in this instance have been considered indicative of an immune response. Twenty-eight of 42 patients tested, or 67 per cent, showed an increase in titer of mouse protective antibodies. If the 13 cases attributed to types 3 and 8 are excluded from the analysis, the percentage of patients showing an immune response rises to 87. As indicated in Table II, the immunological response of the type 3 and 8 cases was inferior, only six of the 13 cases showing an immune response.

Twenty-two, or one-half, of the patients received penicillin within 28 hours of the acute onset of pneumonia. Twelve were treated within 18 hours. The immunological response of the patients treated earlier or later than 28 hours after onset was the same (Table II). Of the early and late groups, agglutinins developed in 46 per cent and 54 per cent, respectively. Mouse protective antibodies increased in titer in 73 per cent and 60 per cent, respectively. Either agglutinins or mouse protective antibodies, or both, increased in the sera of 77 per cent of the patients treated early and in 73 per cent of those treated late.

Exclusion of the type 3 and 8 cases increases the percentage of late cases showing an immune response to 94 as compared to 80 per cent for the early cases. This variation is not considered to be significant, for the difference arises because five of the seven patients in the type 3 and 8 group, who failed to respond immunologically, were treated later than 28 hours after onset. The response of the type 3 and 8 cases treated early was comparable to that shown by the cases due to other types.

Delay in instituting treatment with penicillin did not enhance the immune response of the patients as indicated by a comparison of results in cases treated during the first day of disease with those in cases treated on succeeding days (Figure 1). Figure 1 also shows the duration of the acute pneumococcal infection before penicillin therapy and the immune response in the 22 patients treated within 28 hours of onset. Treatment within seven to 12 hours did not inhibit antibody response. The two cases treated within two
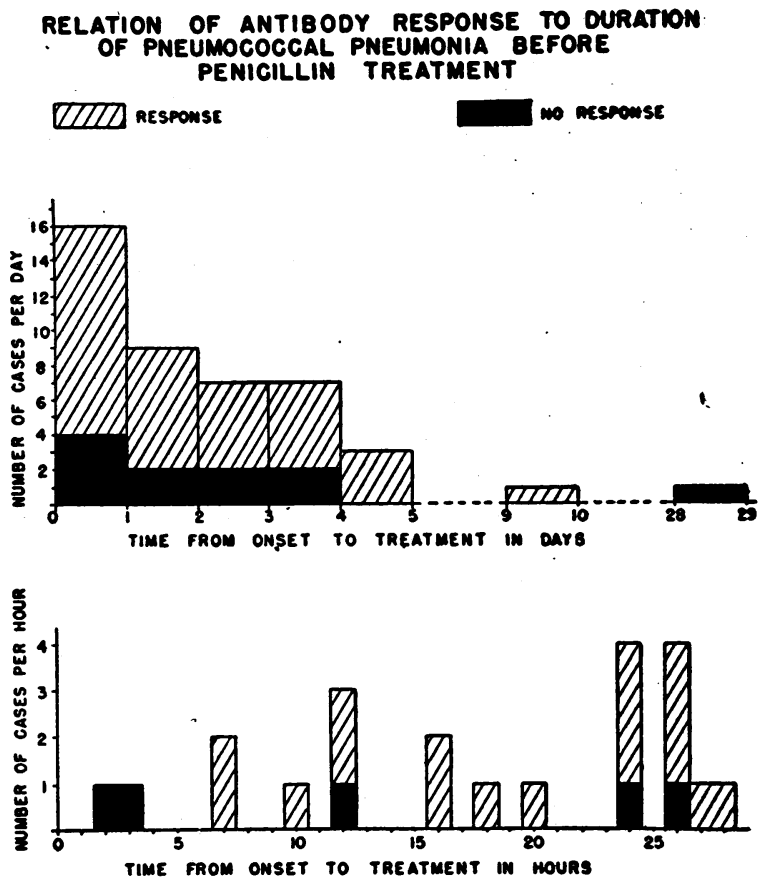

Frc. 1.

and three hours of onset were due to type 8 (case 30 ) and type 1 (case 1) pneumococci, respectively. Both recovered rapidly on penicillin therapy, and neither developed definite roentgenographic evidence of pulmonary infiltration. Observation and immediate treatment of such patients poses the question of when pneumonia begins, a problem in the early pathogenesis of pneumococcal infection illustrated by summaries of the two cases.

Case 1. A 28-year-old technician felt well when she reported for work. Two hours later she experienced brief prodromata of fatigue and malaise followed by a shaking chill and progressive prostration. Examination of the chest showed no abnormal findings. During the next hour she developed a dull pain referred to the right upper quadrant.

Physical examination showed an acutely ill young female with flushed face and injected conjunctivae. The temperature was $39.5^{\circ} \mathrm{C}$., the pulse 112 , and the respirations, 24. There was slight suppression of breath sounds over the right lower lobe, without dullness, friction rub or rales. The leucocyte count was 20,000 with 76 per cent segmented neutrophiles, 18 per cent unsegmented neutrophiles, 4 per cent lymphocytes and 2 per cent monocytes. A sputum specimen obtained at the time of chill showed type 1 pneumococci by direct typing (Quellung). An aerobic blood culture was sterile. Roentgenograms on the first and third days of disease disclosed no evidence of pulmonary infiltration.

The patient was given 30,000 units of penicillin intra- 
muscularly every three hours, receiving the first dose within three hours of onset. Her temperature returned to normal within 24 hours. Leucocyte counts on the second and fifth days of disease were 11,350 and 8,450 , respectively. Symptomatic improvement was equally prompt. Repeated examination failed to disclose any further $a b-$ normal pulmonary findings. She did not develop agglutinins. Mouse protection tests, confirmed on repeat titration, showed protection against $10^{4}$ LD50 in both acutephase and convalescent-phase sera.

Case 30. A 52-year-old school teacher developed an upper respiratory infection two weeks before admission, manifest by nasal stuffiness and a cough productive of yellow mucoid sputum. On the day of admission, he noted increasing fatigue while at work, and that evening suddenly had a shaking chill and felt a sharp pain in his right chest anteriorly. His cough increased and the sputum became rusty. He was seen promptly by his physician, given 300,000 units of procaine-penicillin intramuscularly, and admitted to the hospital.

Physical examination showed a moderately and acutely ill male. The temperature was $39.5^{\circ} \mathrm{C}$., the pulse, 90 , and the respirations, 24. Examination of the chest showed a few fine rales over the left lower lobe. The leucocyte count was 24,800 . A sputum specimen yielded type 8 pneumococci on mouse inoculation. An aerobic blood culture was sterile. A roentgenogram on the first day of illness showed no evidence of infiltration. Two days later, a film showed a few hazy shadows in the cardiophrenic angle of the right lung. These shadows had cleared at the time of repeat examination four days later.

Therapy with procaine-penicillin, 300,000 units once a day, was continued. His temperature returned to normal within 24 hours. Leucocyte counts on the second and fifth days of disease were 10,300 and 7,500 respectively. The few rales in the left lower lobe, on the side opposite that showing questionable infiltration by roentgenogram, disappeared on the third day of disease. He did not develop agglutinins or mouse protective antibodies, but the latest serum available was drawn on the seventh day of illness. A later serum would be necessary in order to exclude definitely an antibody response.

The validity of the diagnosis in the other nine patients who showed no immune response was again examined. Each showed a fall in temperature coincident with the administration of penicillin. All but one, case 41 , an elderly female, had leucocyte counts of 16,000 or more. Four patients, cases $9,21,34$, and 35 had bacteremia. Of these, two showed delayed resolution, and one, a diabetic, developed a lung abscess, empyema and bronchopleural fistula. Case 13 had multiple myeloma and died with recurrent type 2 pneumonia and meningitis. This was the only fatality in the series. Case 17 showed protection against $10^{4}$ LD50 in both acute and convalescent sera. He had been treated for pneumonia, type unknown, at another hospital 11 weeks previously. Case 19, a coal miner, had roentgenographic lesions consistent with silicosis as well as pneumonia. Case 33 showed an increase in mouse protective antibody titer of only 10 LD50. Five of these nine patients unquestionably had pneumococcal infections. The possibility remains, although it is considered to be remote, that the remaining four patients had some other form of pneumonia and were merely carriers of the types of pneumococci found in their sputa.

The development of an immune response was not correlated with the presence or absence of a preceding upper respiratory infection, with the initial or total dosage of penicillin, or with the penicillin treatment schedule. An impression was gained that a poor immune response occurred in certain individuals with severe infections who might have died were penicillin therapy not available. Yet an equivalent number of patients with bacteremia or delayed resolution did develop antibodies.

\section{DISCUSSION}

The data presented in this paper indicate that the antibody response (agglutinins and mouse protective antibodies) of patients with pneumococcal pneumonia treated with penicillin is comparable to that of similar patients treated without specific therapy $(17-20)$ or treated with sulfonamides (1-8). The inferior response of the type 3 and 8 cases conforms with previous observations $(1,6,18)$. The results are likewise in accord with those of Heidelberger and Anderson (8). The method of administration of penicillin is apparently not a factor, for Tompsett et al. (16) found that specific agglutinins developed in approximately the same proportion of cases whether the patients received continuous or discontinuous therapy.

The role of specific antibodies in recovery from pneumococcal pneumonia is not yet clear, particularly since some untreated patients, as well as some of those receiving sulfonamides or penicillin, overcome the infection in the absence of demonstrable immune bodies. Comparable observations have been made in experimental pneumonia in animals (21). On the basis of studies of the influence of penicillin therapy on the immune response in rats, however, Skinsnes and Woolridge (15) suggested that it may be advantageous deliberately to delay active therapy until the infec- 
tion has had adequate opportunity to stimulate antibody defenses. It is of interest to examine the results of earlier immunological studies in animals and the results of studies in humans in the light of this suggestion.

In animals treated with sulfonamides, the immunity produced to pneumococcal infections was related in a quantitative manner to the infecting dose (9) and to the relative antigenicity of the respective types of pneumococci (10). The early development of circulating antibodies and active resistance was not influenced by the administration of sulfonamide (11-13).

Harrison (14) has reported that rabbits treated with penicillin four hours after intradermal inoculation with $10^{-6} \mathrm{ml}$. of a culture of pneumococci did not develop mouse protective antibodies. These rabbits showed no signs of infection. Mice infected with $50 \mathrm{MLD}$ and treated immediately developed no immunity; mice in which penicillin therapy was initiated four to eight hours after infection developed only a moderate increase in immunity. Skinsnes and Woolridge (15) found that early penicillin therapy tended to depress the antibody response of both normal and proteindepleted rats infected with $0.1 \mathrm{ml}$. of culture. But rats treated within two hours developed mouse protective antibodies, and the normal rats developed titers comparable to those recorded in previous groups of rats treated after 12 to 14 hours. Both Harrison (14) and Skinsnes and Woolridge (15) demonstrated that penicillin had no effect on the immune response of animals immunized with large numbers of heat-killed pneumococci.

These data again indicate that the immunity produced was related to the size of the infecting dose. When a small dose was used, as in Harrison's studies with rabbits and mice, the prompt action of penicillin prevented the multiplication of the organisms before sufficient antigen had been elaborated to stimulate antibody formation. When a larger infecting dose was used, as in Skinsnes and Woolridge's studies in rats, early penicillin therapy localized the infection to a small area but did not inhibit antibody formation.

Comparison of immunological studies in man with the results of animal studies is difficult since it is impossible to time the actual introduction of pneumococci in humans. It is possible, as Harrison (14) suggests, that in the usual clinical infection the organisms have an opportunity to pro- voke an immune response during the incubation period, for relatively small amounts of pneumococcal antigen are necessary to provoke an antibody response in humans (22-24). It is apparent that the quantity of antigen present in the usual patient with pneumococcal pneumonia before penicillin treatment is instituted is sufficient to stimulate antibody formation. This may not be the case in streptococcal infections in which early therapy with penicillin will apparently inhibit the antistreptolysin response (25-28). As yet, however, an insufficient number of patients with pneumococcal infections treated within less than seven hours of onset has been observed to determine the effect of such early penicillin therapy on the immune response. The results reported here in the two cases (Nos. 1 and 30) treated within two and three hours of acute onset, raise the question of whether or not penicillin therapy actually reduced the antigenic stimulus.

Comparison of the antibody response in patients treated within 24 hours or less of the acute onset of pneumococcal pneumonia with the response of patients treated after the first day indicates that the immune response was essentially the same in both groups. Antibody formation was not related to the penicillin dosage schedule or to the presence or absence of bacteremia or of a preceding upper respiratory infection. Early penicillin treatment of pneumococcal pneumonia did not suppress the production of agglutinins and mouse protective antibodies. There is thus no indication that penicillin therapy need be delayed in pneumococcal infections in man to permit antibody stimulation.

\section{SUMMARY}

Agglutinins or mouse protective antibodies, or both, developed in the sera of 33 ( 75 per cent) of 44 cases of pneumococcal pneumonia treated with penicillin. Eighty-seven per cent of the cases attributed to types other than 3 and 8 showed an immune response.

Twelve of the patients were treated within 18 hours of the acute onset of pneumonia. Twentytwo, or one-half, were treated within 28 hours. Either agglutinins, or mouse protective antibodies, or both, increased in titer in the sera of 77 per cent of the patients treated within 28 hours and in 73 per cent of those treated later.

The development of an immune response was 
not correlated with the presence or absence of a preceding upper respiratory infection, with bacteremia, with delay in instituting treatment with penicillin, with the initial or total dosage of penicillin, nor with the penicillin treatment schedule.

\section{BIBLIOGRAPHY}

1. Finland, M., and Brown, J. W., Immunological studies in patients with pneumococcus type III pneumonia treated with sulfanilamide and serum. J. Clin. Invest., 1939, 18, 307.

2. Wood, W. B., Jr., and Long, P. H., Observations upon experimental and clinical use of sulfapyridine; mechanism of recovery from pneumococcal pneumonia in patients treated with sulfapyridine. Ann. Int. Med., 1939, 13, 612.

3. Edwards, J. C., Kircher, T. E., Jr., and Thompson, L. D., Effect of sulfapyridine on immune response to pneumococcal infection. Proc. Soc. Exper. Biol. \& Med., 1939, 42, 539.

4. Finland, M., Spring, W. C., Jr., and Lowell, F. C., Immunological studies on patients with pneumococcic pneumonia treated with sulfapyridine. J. Clin. Invest., 1940, 19, 179.

5. Finland, M., Strauss, E., and Peterson, O. L., Antibody response of patients with pneumococcic pneumonia treated with sulfadiazine and sulfathiazole. Ann. Int. Med., 1942, 16, 1.

6. Tillett, W. S., Cambier, M. J., and Dunn, H., Specific antipneumococcal immunity in relation to the chemotherapy of pneumonia. J. Clin. Invest., 1942, 21, 511 .

7. Finland, M., and Shuman, H. I., The type-specific agglutinin response of infants and children with pneumococcal pneumonias. J. Immunol., 1942, 45, 215.

8. Heidelberger, M., and Anderson, D. G., The immune response of human beings to brief infections with pneumococcus. J. Clin. Invest., 1944, 23, 607.

9. McIntosh, J., and Whitby, L. E. H., The mode of action of drugs of the sulphonamide group. Lancet, 1939, 1, 431.

10. MacLeod, C. M., Chemotherapy of pneumococcic pneumonia. J. A. M. A., 1939, 113, 1405.

11. Larson, W. P., Beiter, R. N., and Levine, M., Protective action of sulfapyridine in rabbits infected with pneumococci. Proc. Soc. Exper. Biol. \& Med., 1939, 40, 703.

12. Levine, M., Larson, W. P., and Bieter, R., Active immunity to pneumococci in rabbits protected by sulfapyridine. Proc. Soc. Exper. Biol. \& Med., 1939, 42; 515.

13. Curnen, E. C., and MacLeod, C. M., The effect of sulfapyridine upon the development of immunity to pneumococcus in rabbits. J. Exper. Med., 1942, 75, 77.

14. Harrison, P. E., Comparative effect of penicillin and sulfonamide drugs on the immune response of rabbits to pneumococcus infection and the relation of immunity to bacterial chemotherapy. J. Infect. Dis., 1946, 79, 101.

15. Skinsnes, O. K., and Woolridge, R. L., The relationship of biological defense mechanisms to the antibiotic activity of penicillin. I. The modifying influence of penicillin on the pattern of pneumococcic infection and the immune response in the protein-depleted rat. J. Infect. Dis., 1948, 83, 78.

16. Tompsett, R., Timpanelli, A., Goldstein, O., and McDermott, W., Discontinuous therapy with penicillin. J. A. M. A., 1949, 139, 555.

17. Finland, M., and Sutliff, W. D., Specific cutaneous reactions and circulating antibodies in the course of lobar pneumonia. I. Cases receiving no serum therapy. J. Exper. Med., 1931, 54, 637.

18. Finland, M., and Winkler, A. W., Antibody response to infections with type III and related type VIII pneumococcus. J. Clin. Invest., 1934, 13, 79.

19. Finland, M., and Winkler, A. W., Antibody response to infections with type II and related type V pneumococcus. J. Clin. Invest., 1934, 13, 97.

20. Winkler, A. W., and Finland, M., Ant.body response to infections with the newly classified types of pneumococci (Cooper). J. Clin. Invest., 1934, 13, 109.

21. Wood, W. B., Smith, M. R., and Watson, B., Studies on the mechanism of recovery in pneumococcal pneumonia. IV. The mechanism of phagocytosis in the absence of antibody. J. Exper. Med., 1946, $84,387$.

22. Heidelberger, M., MacLeod, C. M., Kaiser, S. J., and Robinson, B., Antibody formation in volunteers following injection of pneumococci or their typespecific polysaccharides. J. Exper. Med., 1946, 83, 303.

23. Walter, A. W., Schenkein, E. L., and Sutliff, W. D., Mouse-protection titers of sera of volunteers following injection of pneumococci or their typespecific polysaccharides. J. Exper. Med., 1946, 83, 321.

24. Heidelberger, M., MacLeod, C. M., Hodges, R. G., Bernhard, W. G., and diLapi, M. M., Antibody formation in men following injection of four typespecific polysaccharides of pneumococcus. J. Exper. Med., 1947, 85, 227.

25. Weinstein, L., and Tsao, C. C. L., Effect of types of treatment on development of antistreptolysin in patients with scarlet fever. Proc. Soc. Exper. Biol. \& Med., 1946, 63, 449.

26. Goerner, J. R., Massell, B. F., and Jones, T. D., Use of penicillin in the treatment of carriers of $\beta$ hemolytic streptococci among patients with rheumatic fever. New England J. Med., 1947, 237, 576.

27. Kilbourne, E. D., and Loge, J. P., The comparative effects of continuous and intermittent penicillin therapy on the formation of antistreptolysin in hemolytic streptococcal pharyngitis. J. Clin. Invest., 1948, 27, 418.

28. Massell, B. F., Dow, J. W., and Jones, T. D., Orally administered penicillin in patients with rheumatic fever. J. A. M. A., 1948, 138, 1030. 